\title{
CONTEMPORARY RESEARCH ON THE PATHOLOGY OF RHEUMATIC DISEASE REVIEWED IN THE LIGHT OF 100 YEARS OF CELLULAR PATHOLOGY*
}

\author{
BY
}

\author{
D. H. COLLINS \\ Professor of Pathology, University of Sheffield
}

(RECEIVED FOR PUbLICATION JULY 10, 1957)

Perhaps in no field of human disease, more than in the field of rheumatism and connective-tissue disorders, have such great technical advances been made in methods of biological study. Some of the knowledge thus gained and some of the ideas suggested are at present difficult to apply directly to the clinical problems that face rheumatologists. Moreover, some of the newly discovered facts seem at first sight to be incompatible with traditional pathological teaching.

These are the reasons that led me on to shape this address in the form of a short but broad review of what is happening in rheumatism on the pathological side, and to attempt, with a historical glance backwards, to put recent work in proper perspective.

\section{Virchow's Die Cellularpathologie (1858)}

It is indeed little more than a century since the cellular organization of living creatures was observed and, in medicine, the concept of the nature and mechanism of disease thereupon underwent a great revolution. Pathology expanded into the system of cellular pathology that still guides our teaching and investigations, whereby we believe that all the manifestations of disease, whatsoever its cause, are the result of vital reactions of the cellular tissues of the body or disturbances of cellular functions.

One hundred years ago Rudolf Virchow, then a young professor in Berlin, was laying the foundations of pathology as we know it to-day. Early in 1858 he gave a course of postgraduate lectures with the purpose of publicizing all that was then known about

\footnotetext{
* Paper delivered at a Plenary Session of the Ninth International Congress on Rheumatic Diseases, Toronto, June 24, 1957.
}

the cellular basis of life "out of which also the science of pathology has now to be constructed". The lectures were published in the same year in the now famous book Die Cellularpathologie (Virchow, 1858).

Had Virchow written nothing else, and he was a most prolific writer, this book would have marked him as among the greatest of the founders of modern medical science. It of course containso certain errors and false deductions resulting from? the contemporary limitations of knowledge, but most of the principles there enunciated have stood firm for a hundred years and remain valid to-day.

It is therefore appropriate to bring the centenary of cellular pathology to the notice of this great international congress of doctors meeting 4,000 miles away from Berlin in another city that in the intervening years has itself risen to be a great centre of academic medicine.

The results of modern and intensive research on cell structure and metabolism have not demolished the principles of cellular pathology; rather have they added new meaning by enabling us to interpret static morphology in terms of minutely analysed cell dynamics. To-day, for example, we no longer need doubt that "cloudy swelling" of parenchymal cells (Virchow's trübe Schwellung) is a significant change not due to artefact. Virchow was quite correct in interpreting it as the excessive storage or absorption of nutrient substances by stimulated cells. We now have evidence that water is sometimes retained by these cells (Popják, 1948), together with salts and enzymes in the mitochondria (Cameron, 1956); in other circumstances the cells may appear swollen and granular because of the excessive absorption of proteins (Spector, 1954; 
Oliver, MacDowell, and Lee, 1954). The results of such investigations and of numerous other researches into cellular metabolism and the structure and function of parenchymatous organs serve only to confirm the doctrines of cellular pathology and to extend their sphere of useful application.

\section{The Intercellular Substances of Connective Tissue and Their Dependence upon Living Cells}

In the field of connective-tissue pathology, however, it is sometimes harder to be sure of the direction in which we are moving, because scientists have paid far more attention to the intercellular substances than to the cells. We now possess much very valuable information about the chemical, physico-chemical, and ultramicroscopic structure of matrix and fibres, but we still know too little about the relationship between cells and intercellular substances.

Much research has gone into the question of fibrillogenesis-whether collagen fibres first form within the fibroblast, as the older histologists claimed, on the surface of the fibroblast (Porter, 1951; Buck, 1953; Wassermann, 1954), or in matrix remote from the fibroblast (Doljanski and Roulet, 1933). That collagen fibres can be formed in vitro (Nageotte, 1927; Jackson, 1953) shows that the physico-chemical circumstances necessary for fibrillogenesis can be attained without the actual presence of cells. It is, however, surely true, as Stearns (1940) has shown in her studies of granulation tissue in the Clark-Sandison chamber, that, in the living body, the presence of fibroblasts is essential for the production of fibres, even though their final elaboration may actually take place outside the cell body. In plain language, it is living cells, fibroblasts, that set the stage and prepare the reagents for the experiment that culminates in the generation of the collagen fibre.

The diffuse matrix or amorphous ground substance of connective tissue has been investigated as extensively as the fibrous elements, and perhaps, from the pathologist's point of view, more profitably. From the complexities of mucopolysaccharide chemistry the fact now emerges that there is a measure of uniformity of composition within certain tissues (Meyer, Davidson, Linker, and Hoffman, 1956). Mucopolysaccharides are exceedingly important substances because they are endowed with physico-chemical properties that enable them to perform biological functions of a far greater range than those merely of cement or ground substances. They are viscous in the joint cavity and resilient in cartilage. Hyaluronic acid is hydrophilic (Meyer and Rapport, 1951), and the sulphated polysaccharides are capable of functioning as ion exchange substances (Boyd and Neuman, 1951). On account of these properties the mucopolysaccharide ground substance serves as "a selective and controlled barrier" (Dorfman, 1954) between the circulating blood and the cells. Mucopolysaccharides are concerned in the formation of collagen fibres (Meyer, 1947; Curran, 1953), and, less certainly perhaps (Hass, 1956), in calcification. With these "acellular functions" of ground substance in mind, we may also reflect for a moment on the recently proven property of bone-salt crystals to effect mineral exchanges, rapidly and to an important degree, by surface action, a property that seems to be independent of cellular control (Engfeldt and Hjertquist, 1954; McLean and Urist, 1955).

It cannot therefore be so strictly true, as was earlier thought, that every biological activity in the body is mediated by the cells, and in the connective tissues there is a far from negligible degree of spontaneous physico-chemical interaction between the inter-cellular substances and their environment.

Nevertheless, life resides in the cells; it is only they that respire and die. Karl Meyer (1957) has written:

"... it would be most useful to consider the whole of the connective tissues as a highly integrated organ, in quantity the largest in the mammalian body, whose maintenance and function depend on cellular metabolism to the same extent as any other organ."

In the connective tissues, as much as elsewhere, pathological lesions are the result of cellular reaction, involving their proliferation or degeneration or an alteration in their function.

Virchow had many interesting, but now forgotten, things to say about the organization of connective tissues that are very pertinent to our present-day studies. He introduced the idea of "cell-territories" (Zellenterritorien):

"we find in the organization of animals a peculiarity scarcely ever to be seen in vegetables, namely, the development of large masses of intercellular substance."

This, he concludes is "dependent in a certain definite manner upon the cells" (Virchow, 1858, trans. 1860).

Virchow's picture of "nutritive juices" being conveyed around the connective tissues by an anastomosing network of cellular tubes is obviously outmoded. Nowadays, we know that the intercellular substances provide not only structural support but a physico-chemical system for the carriage and diffusion of metabolites. In this way 
the cells depend upon the interceliular matrix substance-and the matrix depends upon the cells.

Two cellular sources of the diffuse matrix, which we now identify with the mucopolysaccharides, have been postulated: the tissue mast-cell (AsboeHansen, 1950), and the fibroblast (Meyer, 1947; Gersh and Catchpole, 1949) or its variants, such as the synovial cell, as has been demonstrated in tissue culture (Vaubel, 1933) and in metastases of synovioma (Meyer, 1947). The mast-cell does certainly contain mucopolysaccharide in the form of heparin and perhaps in other forms. It is a cell that is only distinguishable when functionally differentiated; it may well take its origin from the same undifferentiated mesenchymal stem-cells as the fibroblast (Drennan and Beare, 1954). There is now, however, a great body of evidence that the connective-tissue mucins are the product of connective-tissue cells, but of no one particular type. Our own recent observations on fields of intramembranous ossification in man illustrate this (Curran and Collins, 1957).

The formation of membrane bone takes place in a field of tissues where there is a proliferation of cells having a great capacity for differentiation, and where also there is a great increase in mucopolysaccharide, much of it is sulphated. Using radioactive sulphate as a label, it can be shown by autoradiography that mucopolysaccharides are the product of living cell bodies; that at least one of the components of this very important matrix substance has to pass through the body of a living cell. Moreover, it is not only the fibroblasts, osteoblasts, chondroblasts, or chondrocytes that are thus engaged in the manufacture of matrix, but quite distinctly the capillary endothelial cell (Curran, 1957). It is almost certainly erroneous, therefore, to suppose that matrix forms, reacts, or even degenerates in the living body through intrinsic processes alone without the participation or outside the influence of the living cells.

\section{Osteo-Arthritis}

Osteo-arthritis is a case in point. In the main, this is a local disease; that is to say that the cycle of pathological changes in each joint progresses independently of systemic influences or of what is happening in other joints (Collins, 1949). All will agree that it is a disruption of articular cartilage that initiates the progressive structural changes that lead in turn to eburnation, osteophytes, remodelling of the bone ends, deformity of the joint, and painful capsular contractures (Lloyd-Roberts, 1953). Moreover, it is apparent that a uniform pattern of pathological changes succeeds the primary lesion of articular cartilage whether this is caused by acute or by chronic trauma or by the processes of ageing. Pathological research into osteo-arthritis is, therefore, quite rightly largely directed upon the initial changes in the cartilage, but the influences of ageing and trauma must not be studied only in the fibrillar and other intercellular substances; they must be sought also, and perhaps primarily, in the cellschondroblasts and chondrocytes. Current studies in my own department show a disturbed sulphate utilization by chondrocytes in certain areas of osteoarthritic cartilage, and other functions of these cells might profitably be studied.

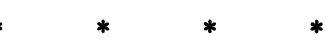

I propose now to leave this aspect of pathologythe relationship between the cells and matrix of connective-tissues-and to turn to another matter: namely, the extent to which histopathology can be relied upon in the identification and diagnosis of rheumatoid arthritis and what can be properly deduced from histopathological studies about causes.

\section{Rheumatoid Arthritis}

The pathological features of rheumatoid arthritis have now been so adequately described that it is possible to define the disease in pathological terms if we take a broad enough view (Collins, 1957).

There is no single histopathological change that will identify rheumatoid arthritis.

The most constant and characteristic lesion is the chronic proliferative synovitis. Also characteristic but less constant are the progressive granulomatous changes within the rheumatoid joint, the subcutaneous nodules, and, much less readily available, nodules of similar form that sometimes appear in the fibrous structure of viscera, for example, in the heart (Baggenstoss and Rosenberg, 1944; Sokoloff, 1953), lungs (Sinclair and Cruickshank, 1956; Ellman, 1956), sclera (Goar and Smith, 1952), or dura mater (Maher, 1954). Other less characteristic and inconstantly associated lesions are lymphoid foci in somatic tissues, lymphadenopathy, and such general inflammatory processes as arteritis, pericarditis, and dermatitis.

There is a certain pattern of granulomatous tissue reaction in the joints and in the nodules that is characteristic of, but not specific to, rheumatoid arthritis. In these lesions the granulomatous reaction is seen to be composed of:

(a) Proliferation of vascular and connectivetissue cells; 
(b) Local accumulation of lymphocytes, plasma cells, and leucocytes;

(c) Necrosis;

(d) Exudate, often rich in mucopolysaccharides that with $(c)$ gives rise to the picture of fibrinoid necrosis.

Even when focal, as in the subcutaneous nodule, this histopathological syndrome may be mimicked by a few other lesions, notably granuloma annulare, but when viewed as a whole in structure, site, and course of development, the subcutaneous nodule is one of the most distinctive lesions of the disease.

\section{The Limitations of Histopathology}

It is the experience of general pathologists that the histological identification of the nature and cause of an inflammatory lesion is a much more uncertain procedure than is the recognition of most varieties of neoplasm. The history of cellular pathology contains many examples of over-confidence in the specificity of histopathological appearances in this field that has later proved to have been misjudged. The epitheloid-cell tubercle, once thought always to indicate tuberculosis, is now known to form as a response to such unrelated agents as necrotic fat or beryllium.

When we break down our pathological picture even to the limited extent of concentrating only on a proliferative synovitis with lymphoid foci, we begin to be less sure of the identity of the lesions we are considering. This picture is characteristic of rheumatoid arthritis, but we see it in the case of intermittent hydrarthrosis and in involvement of the peripheral joints in ankylosing spondylitis. This fact alone is not sufficient to establish the identity of these two diseases with rheumatoid arthritis or with each other: it is a piece of evidence that must be weighed with other evidence.

A great difficulty arises, and has risen, here in experimental studies on the induction of inflammatory arthritis in animals. To what extent is it permissible to draw conclusions about rheumatoid arthritis in man from the comparative pathology of limited lesions in, say, the synovial tissues? All kinds of agents have been employed in causing granulomatous arthritis in small animals, for example, streptococci (Cecil, Angevine, and Rothbard, 1939), pleuropneumonia organisms (Findlay, 1946), turpentine (Jordan, 1938), formalin (Selye, 1949), and antigenic serum (Klinge, 1933), without conclusive evidence that a parallel could be established with rheumatoid arthritis of man. One agent with which I have been especially concerned is the micro-organism Erysipelothrix rhusiopathiae. The interest of this organism is that it causes a naturally occurring disease in hogs; this, as we pointed out many years ago, more closely simulates rheumatoid arthritis both pathologically and clinically than any other natural disease of animals (Collins and Goldie, 1940; Hughes, 1955; Sikes, Neher, and Doyle, 1956). Moreover, it can be induced by exceedingly small inoculations of the organism in hogs (Collins and Goldie, 1940), and in rabbits (Goldie and Collins, 1956). The synovial lesions very closely resemble those of rheumatoid arthritis, they are chronic and in the later stages often sterile. Moreover, lesions of fibrinoid necrosis or of arteritis may sometimes be found (Collins and Goldie, 1940). But this is a bacterial disease with localization of the bacteria in the joints, at least temporarily. Now, all the evidence collected over the years is against this being the case in human rheumatoid arthritis. Moreover, were rheumatoid arthritis a metastatic bacterial infection, it is at least probable that cortisone would have uncovered the occult infection in the joints, since it tends rather generally to aggravate bacterial infections (Cavallero, 1954). Cortisone seemed to favour rather than impede the induction of arthritis in rabbits by $E$. rhusiopathiae (Goldie and Collins, 1956).

Histopathological appearances are the expression of tissue reaction, and their variety depends wholly upon the capacity of the affected tissues to develop different patterns of reaction to different irritants. The experimental approach to arthritis research has shown us that chronic proliferative synovitis of an almost uniform pattern can be induced by a large number of unrelated agents. Therefore, the histopathology of the joints is, on its own, unacceptable evidence in establishing the cause of human rheumatoid arthritis.

In interpreting synovial histopathology in man, we can justly use the term "rheumatoid type of synovitis" for the now well-known combination of appearances, because experience has taught us that in the great majority of cases where this is seen there is strong collateral evidence for the diagnosis of rheumatoid arthritis. It cannot, I think, be assumed that these appearances in man, any more than in animals, are necessarily the reaction to a single pathogenic agent or brought about by a uniform pathogenic mechanism. It seems illogical therefore to identify them categorically with rheumatoid arthritis, if at the same time we regard rheumatoid arthritis as a disease that has a nosological identity and, therefore, a consistent aetiology that will eventually be discovered. 


\section{The Fibrinoid Lesion}

It is a general rule that when an observed pathological change is of a simple, more primitive, or basic character, the likelihood is diminished of its being peculiar to any particular disease process or of its indicating a reaction to any specific agent of disease.

Too much should not, therefore, be expected from observing and comparing fibrinoid lesions in various situations and in various diseases, the causes of which are still unknown. Over the past 15 years the concept of "collagen disease" (Klemperer, Pollack, and Baehr, 1942; Klemperer, 1950), though much abused and misinterpreted, has proved valuable in so far as it has directed intensive study upon the mechanism of connective-tissue lesions, but it was never intended to suggest that these diseases might have a common aetiology or that the ultimate cause of any of the diseases might lie in a spontaneous degeneration of collagen or matrix. This last view is scarcely tenable if we respect the doctrines of cellular pathology, and I see no reason why the fibrinoid focus, like the proliferative granuloma and the lymphocytic reaction, should not be regarded as a response to some noxious agent altering the form and function of both cellular and acellular elements of the connective tissues and mainly mediated through injury to the cells.

The fibrinoid lesion requires further study, but it is now clear that collagen fibril degeneration plays a relatively insignificant part (Altshuler and Angevine, 1949; Bien and Ziff, 1951), and that fibrin contributes very little to it (Glynn and Loewi, 1952). What is of much significance is the great accumulation of acid mucopolysaccharides, together with variable fractions of plasma protein (Gitlin, Craig, and Janeway, 1957).

It is seemingly an exudate of rather peculiar composition, derived from stimulated cells in the walls of blood-vessels that gives the distinctive character to the fibrinoid focus, and to the fibrinoid changes seen around small vessels in many different diseases. The exudate differs from that of ordinary inflammation in being relatively cell-free and relatively fibrin-free. The process has been termed "serous inflammation", and has been identified both in parenchymatous organs (Rössle, 1943) and in the connective tissues (Altshuler and Angevine, 1949). The abundance of mucopolysaccharides in the exudate and our recent demonstration (Curran and Collins, 1957; Curran, 1957) that the capillaries are among the major sites of sulphate utilization serve to confirm the important role of the vascular cells in this particular pattern of inflammatory reaction. The concept of "serous inflammation", though obscurely named, is consonant with the principles of cellular pathology, and it may prove to be very relevant to the problems presented by the fibrinoid lesion and the "collagen diseases".

\section{Conclusions}

The principles of cellular pathology have stood the test of 100 years of cumulative experience and of research by advanced techniques.

Recent work on the inter-cellular substances of $\overrightarrow{0}$ connective tissues reveals that, although not "alive", $\vec{\overrightarrow{ }}$ they manifest biological activities independently of $\vec{\omega}$ cell function, through a range of physico-chemical interactions with their environment. It is, however, ? quite possible to expand our system of cellular $\vec{\sigma}$ pathology to embrace this new knowledge, and in $\omega$ pathology we must regard connective tissue as a symbiotic whole-cells and inter-cellular matter-as Virchow had indeed conceived it.

A field for new investigations on this basis is $\vec{c}$ to be seen in the cartilage changes of osteo-arthritis. $\mathbb{D}$

Experience over the years has shown us certain $\overrightarrow{\mathbb{D}}$ limits within which conclusions can be drawn from 3 histopathological observations. This is especially so $\stackrel{\Phi}{-}$ in the case of inflammatory diseases, where the more $\vec{\theta}$ we break down the pathological picture, the less sure of we become of the specific identity of the lesion are considering.

It is for this reason that rheumatoid arthritis can be defined in terms of the whole pathological picture but cannot be identified by any single histopathological feature. For the same reason, the histo- $~$ pathology of experimental arthritis is, on its own, $\overrightarrow{\overrightarrow{0}}$ unacceptable evidence in deducing the possible cause 3 of human rheumatoid arthritis, and the "fibrinoid lesion" is an inadequate basis for claiming the identity of a number of otherwise somewhat divergent diseases all of unknown causation.

In regard to the fibrinoid lesion, I have tried to direct attention to the stimulated activity of capillary endothelium and other cells in forming the mucopolysaccharide-rich exudate and to divert attention from the "degenerative" character of the lesion.

The last few years have seen the collection of a great amount of miscellaneous and extremely useful knowledge about the connective tissues and $N$ the rheumatic diseases. What we must now seek is its integration. Only in this way, I believe, shall $\mathrm{N}$ we be led to a true understanding of the nature of $\omega$ the rheumatic diseases and thence to a discovery of their causes.

\section{REFERENCES} Altshuler, C. H., and Angevine, D. M. (1949). Amer. J. Path., 25,

Asboe-Hansen, G. (1950). Annals of the Rheumatic Diseases, 9, 149. 
Baggenstoss, A. H., and Rosenberg, E. F. (1944). Arch. Path. (Chicago), 37, 54

Bien, E. J., and Ziff, M. (1951). Proc. Soc. exp. Biol. (N.Y.), 78, 327 Boyd, E. S., and Neuman, W. F. (1951). J. biol. Chem., 193, 243.

Buck, R. C. (1953). J. Path. Bact., 66, 1.

Cameron, G. R. (1956). "New Pathways in Cellular Pathology". Arnold, London.

Cavallero, C. (1954). In "Connective Tissue in Health and Disease", ed. G. Asboe-Hansen, p. 214. Munksgaard, Copenhagen.

Cecil, R. L., Angevine, D. M., and Rothbard, S. (1939). Amer. J. med. Sci., 198, 463.

Collins, D. H. (1949). "The Pathology of Articular and Spinal Diseases", chap. 5, p. 74. Arnold, London. (1957). Acta med. scand., In press.

and Goldie, W. (1940). J. Path. Bact., 50, 323.

Curran, R. C. (1953). Ibid., 66, 271.

(1957). Ibid., 74. In press.

and Collins, D. H. (1957). Ibid, 74,7

Doljanski, L., and Roulet, F. (1933). Virchows Arch. path. Anat., $291,260$.

Dorfman, A. (1954). In "Connective Tissue in Health and Disease", ed. G. Asboe-Hansen, p. 81. Munksgaard, Copenhagen.

Drennan, J. M., and Beare, J. M. (1954). J. Path. Bact., 68, 345.

Ellman, P. (1956). Postgrad. med. J., 32, 370.

Engfeldt, B., and Hjertquist, S.-O. (1954). Acta path. microbiol. scand. 35, 205.

Findlay, G. M. (1946). Annals of the Rheumatic Diseases, 5, 153.

Gersh, I., and Catchpole, H. R. (1949). Amer. J. Anat., 85, 457.

Gitlin, D., Craig, J. M., and Janeway, C. A. (1957). Amer. J. Path., 33, 55 .

Glynn, L. E., and Loewi, G. (1952). J. Path. Bact., 64, 329.

Goar, E. L., and Smith, L. S. (1952). J. Amer. med. Ass., 148, 889.

Goldie, W., and Collins, D. H. (1956). J. Path. Bact., 71, 425.

Hass, G. M. (1956). In "The Biochemistry and Physiology of Bone", ed. G. H. Bourne, chap. 24, p. 767. Academic Press, New York.

Hughes, D. L. (1955). Brit. vet. J., 111, 183

Jackson, S. Fitton (1953). In "Nature and Structure of Collagen", ed. J. T. Randall, p. 140. Butterworth, London.

Jordan, E. P. (1938). Arch. Path. (Chicago), 26, 274.

Klemperer, P. (1950). Amer. J. Path., 26, 505.

(1950). Amer. J. Path., 26, 505. Pollack.

Klinge, F. (1933). Ergeb. allg. Path. path. Anat.. 27, 1

Lloyd-Roberts, G. C. (1953). J. Bone Jt. Surg., 35b, 627.

McLean, F. C., and Urist, M. R. (1955). "Bone: An Introduction to the Physiology of Skeletal Tissue", p. 36. University of Chicago Press, Chicago.

Maher, J. A. (1954). A.M.A. Arch. Path., 58, 354.

Meyer, K. (1947). Physiol. Rev., 27, 335.

(1957). In "The Harvey Lectures 1955-56", p. 88. Academic Press, New York.

Davidson, E., Linker, A., and Hoffman, P. (1956). Biochim. biophys. Acta, 21, 506.

- and Rapport, M. M. (1951). Science, 113, 596.

Nageotte, J. (1927). C.R. Soc. Biol. (Paris), 96, 172, 464.

Oliver, J., MacDowell, M., and Lee, Y. C. (1954). J. exp. Med., 99. 589.

Popják, G. (1948). J. Path. Bact., 60, 75.

Porter, K. R. (1951). In "Connective Tissues", Trans. 2nd Conference, p. 126. Josiah Macy, Jr., Foundation, New York.

Rössle, R. (1943). Virchows Arch. path. Anat., 311. 252.

Selye, H. (1949). Brit. med. J., 2, 1129.

Sikes, D., Neher, G. M., and Doyle, L. P. (1956). Amer. J. Path., 32, 1241 .

Sinclair, R. J. G., and Cruickshank, B. (1956). Quart. J. Med., 25 , 313.

Sokoloff, L. (1953). Amer. Heart J., 45, 635.

Spector, W. G. (1954). J. Path. Bact., 68, 187.

Stearns, M. L. (1940). Amer. J. Anat 66, 133.

Vaubel, E. (1933). J. exp. Med., 58, 85.

Virchow, R. (1858). "Die Cellularpathologie", 1st ed. Hirschwald, Berlin.

(1860). "Cellular Pathology", trans. F. Chance from 2nd ed. Lecture 1. pp. 14-15. Churchill, London.

Wassermann, F. (1954). Amer. J. Anat., 94, 399.

Recherches actuelles sur la pathologie de la maladie rhumatismale à la lumière de $\mathbf{1 0 0}$ ans de pathologie cellulaire

\section{CoNCLUSIONS}

Les principes de la pathologie cellulaire ont supporté l'épreuve de 100 ans d'expérience accumulée et de recherches par des procédés avancés.

Les travaux récents sur les substances intercellulaires des tissus conjonctifs révèlent que, sans être "vivantes", ces substances manifestent des actions biologiques indépendantes de la fonction cellulaire par une série d'interactions physico-chimiques avec leur milieu. Il est, cependant, bien possible d'étendre notre système de pathologie cellulaire de manière à embrasser ces nouvelles connaissances, et en pathologie il nous faut considérer le tissu conjonctif comme une entité symbiotiquecellules et matière intercellulaire-comme Virchov l'a de fait conçu.

Un champ nouveau de recherches dans ce sens peut se voir dans les altérations cartilagineuses de l'ostéoarthrite.

L'expérience de ces dernières années a révélé, toutefois, des limites dans lesquelles on peut tirer des conclusions des observations histopathologiques. Ceci concerne particulièrement le cas des maladies inflammatoires où, plus on détaille le tableau pathologique, moins on reconnaît l'identité spécifique de la lésion étudiée.

C'est pour cette raison que l'on peut définir l'arthrite rhumatismale en tant qu'un tableau pathologique entier mais on ne peut pas l'identifier par un seul trait histopathologique. Pour la même raison, l'histopathologie de l'arthrite expérimentale seule ne suffit pas pour déterminer la cause de l'arthrite rhumatismale humaine, et la "lésion fibrinoïde" ne constitue pas une preuve d'identité d'un certain nombre de maladies autrement un peu divergeantes dont la cause n'est pas connue.

A propos de la lésion fibrinoïde, j'ai essayé d'attirer l'attention à l'activité stimulée de l'endothélium capillaire et des autres cellules dans la formation de l'exsudat riche en mucopolysaccharide et détourner l'attention du caractère de "dégénérescence" de cette lésion.

$\mathrm{Au}$ cours de ces dernières années beaucoup de connaissances variées et extrêmement utiles sur les tissus conjonctifs et les maladies rhumatismales se sont accumulées. Maintenant il faut viser à leur intégration. C'est la seule voie menant à la connaissance de la nature des maladies rhumatismales et, par conséquent, à la découverte de leurs causes.

\section{Investigaciones actuales sobre la patología de la enfermedad} reumática a la luz de $\mathbf{1 0 0}$ años de patología celular

\section{CONCLUSIONES}

Los principios de la patología celular han soportado la prueba de 100 años de experiencia acumulada y de investigaciones por métodos avanzados.

Los trabajos recientes sobre las substancias intercelulares de los tejidos conjunctivos revelan que, sin ser "vivas", éstas desempeñan acciones biológicas independientes de la función celular por una serie de interacciones físico-químicas con su medio ambiente. Es perfectamente posible, sin embargo, ensanchar nuestro sistema de patología celular para incluir estos conocimientos nuevos y en patología hay que considerar el tejido conjuntivo-células y materia intercelularcomo una entidad simbiótica, en conformidad con la concepción de Virchov.

Un campo nuevo de investigaciones en este sentido se abre en las alteraciones cartilaginosas de la ósteoartritis.

La experiencia de los últimos años ha revelado, sin embargo, los límites dentro de los cuales se pueden sacar conclusiones de observaciones histopatológicas. Esto se aplica en particular a las enfermedades inflamatorias donde, cuanto más se fracciona el cuadro patológico tanto menos se reconoce la identidad específica de la lesión considerada.

Por esta razón se puede definir la artritis reumatoide 
como un cuadro patológico entero, pero no se la puede. identificar por un solo rasgo histopatológico. Por la misma razón, la histopatología de la artritis experimental sola no basta para determiner la causa de la artritis reumatoide humana, y la "lesión fibrinoide" no constituye una marca de identificación de ciertas enfermedades otramente algo divergentes y de causa desconocida.

Respecto a la lesión fibrinoide, he tratado aquí de atraer la atención hacia la actividad estimulada del endotelio capilar y de otras células en la formación del exudado rico en mucopolisacaridos y desviar la atención del caracter "degenerativo" de esta lesión.

En el curso de los últimos años se recogieron muchos conocimientos, variados y muy útiles, sobre los tejidos conjuntivos y las enfermedades reumáticas. Se trata ahora de integrarlos. Este es el único camino conduciendo al conocimiento de la naturaleza de las enfermedades reumáticas $\mathrm{y}$, por consiguiente, a la descubierta de sus causas. 